\title{
THE AESTHETICS OF SMELLS: THE SENSE OF SMELL AND NURSING
}

\author{
Antônio de Miranda Wosny ${ }^{1}$ \\ Alacoque Lorenzini Erdmann ${ }^{2}$ \\ Paulo Belli Filho ${ }^{3}$ \\ Joséte Luzia Leite
}

Wosny AM, Erdman AL, Belli Filho P, Leite JL. The aesthetics of smells: the sense of smell and nursing. Rev Latino-am Enfermagem 2008 março-abril; 16(2):320-3.

This study aims to present reflections on the meaning of olfactory sensations and perceptions, as well as their relevance as a phenomenon present in Nursing practice. It stresses the importance of the smells' chemical language in the hospital environment, emphasizing some deductions about the aesthetics of smells from the Nursing perspective. The authors conclude that a deeper aesthetic/philosophical and technical/scientific comprehension of smell emanations will contribute to human care, especially in Nursing diagnoses and prescriptions, environmental quality regulation and therapeutics.

DESCRIPTORS: odors; smells; nursing

\section{ESTÉTICA DE LOS OLORES: EL SENTIDO DEL OLFATO Y LA ENFERMERÍA}

Este estudio presenta reflexiones acerca del significado de las percepciones y sensaciones olfativas y suya pertinencia como fenómeno presente en la práctica de la Enfermería. Destaca la importancia de la linguage química de los olores en el ambiente hospitalario, puntuando algunas deducciones sobre la estética de los olores por la enfermería. Concluye que la mayor comprensión estético/filosófica y técnico/científica de las emanaciones odorantes podrá contribuir para el cuidado humano, especialmente en el diagnóstico y prescripción de Enfermería, vigilancia de la calidad ambiental y terapéutica.

DESCRIPTORES: olores, olfato, enfermería

\section{ESTÉTICA DOS ODORES: O SENTIDO DO OLFATO E A ENFERMAGEM}

Este estudo apresenta reflexões acerca do significado das percepções e sensações olfativas e sua pertinência como fenômeno presente na prática da Enfermagem. Destaca a importância da linguagem química dos odores no ambiente hospitalar, pontuando algumas deduções sobre a estética dos odores pela enfermagem. Conclui que a maior compreensão estético/filosófica e técnico/científica das emanações odorantes poderá contribuir para o cuidado humano, especialmente no diagnóstico e prescrição de Enfermagem, vigilância da qualidade ambiental e terapêutica.

DESCRITORES: odores; olfato; enfermagem

\footnotetext{
${ }^{1}$ RN, PhD in Nursing, Adjunct Professor; ${ }^{2}$ RN, PhD in Nursing Philosophy, Full Professor; e-mail: alacoque@newsite.com.br; ${ }^{3}$ Sanitarian Engineer, PhD in Industrial and Environmental Chemistry, Adjunct Professor. Santa Catarina Federal University, Brazil; ${ }^{4}$ RN, Emeritus Professor, Federal University of Rio de Janeiro State, Brazil, e-mail: joluzia@gmail.com
} 


\section{OLFACTORY EXPERIENCES... SMELLS... NURSING}

"Present sensations evoke absent
sensations"(1)

Sensations determine human existence. It may be true that olfactory experiences mediate the first contact of the human being with the world, through the mother's smell, which reinforced his survival and constituted the beginning of his knowledge. People accumulate olfactory experiences that, through their characteristics and stimuli, consolidate the olfactory imaginary of the smell phenomena.

Nursing activities are developed in a scenario with multiple stimuli that require the human senses. Olfactory perceptions are essential in the space of hospital care, considering their intensity and constancy in daily life. Florence Nightingale inspired the consideration of the sense of smell, as she cared about the environment and the need for fresh air through techniques for care instrumentation ${ }^{(2,3)}$.

In the contemporary context, the space assigned to smells has been extremely restricted and the existing prevalence is for the odorless. Thus, the culture of fragrances makes room for the inexistence of smells in social spaces. The technology available for the exclusion of environmental smells from hospitals contributes to new smells of septic products. However, these smells may follow the human being with the singularity of their smell. Some situations are unpleasant for one's sense of smell, causing general discomfort. In these cases, whenever possible, the measures used aim at the control, dispersion or elimination of such smells. Furthermore, these individual smells can indicate multiple meanings, such as clinical signs, ethnic characters and culturally important values for both the caregiver and the patient.

Some studies ${ }^{(4-7)}$, aimed at presenting reflections on this subject, have investigated the sense of smell, olfactory sensitivity and smells in their sociocultural and historical dimensions. They clarify some of the legacies that discredited the human sense of smell, removing it from the evolutionary process of the species and the nature of the deodorized world.

\section{THE SENSE OF SMELL... KNOWLEDGE FOR NURSING ...}

In ancient times, philosophers, who studied sensations, presented the smells and their "semiformed" nature as a structure characterized as "lighter that the water and denser than the $\operatorname{air}^{\prime \prime(7)}$; and which, due to the complexity of their classification in categories, are limited to their pleasant and unpleasant characteristics $^{(7)}$. On the other hand, modern science and technology consider the supremacy of the sense of sight and hearing. Sight is presented as the eligible sense to qualify most of the sensory reflections in the Western point of view. The sensation, as the representation of an object or impression of the senses, differs from the subjective representation. Nevertheless, Kant considers the sensation as a qualification or subjectivity of the perceived object or feeling that things evoke ${ }^{(8-11)}$.

The philosopher Montaigne defends an odorless world. According to Montaigne's point of view, the best trait a human being can have is the lack of smell; he also said the purest breath is both sweet and odorless, like in the case of healthy children ${ }^{(12)}$. Moreover, the emanations from the smells aggregated to the body may be a sign of some natural odor defect, which has generated poetic aphorisms, such as the ones by Marcial and Horácio, suggesting that a good smell is a sign of bad smell, or that people who have a good smell in life will have a bad one when they are dead ${ }^{(12)}$.

Deodorizing habits are found in reports from Western and Greek-Roman cultures and have been adopted by important current cultures ${ }^{(7)}$, promoting a real body and environmental asepsis. Thus, the sense of smell has missed its space in many activities and, today, it is kept in the chemical manipulation of essences or aromatic products.

Contrary to empiricist and rationalist concepts, the Gestalt and Husserl's Phenomenology define the unimportant sensation of perception, for instance the things a person can feel and perceive in their totality and which have a meaning ${ }^{(13)}$. From the empiricist's point of view, knowledge has its origin in the sensitive experience, in the senses, sensations and perceptions, and depends on external stimuli: "all the ideas derive from the sensation or reflection"(14).

Condillac enlarges Locke's ideas in order to explain how the language of action analyses thought ${ }^{(15)}$. The language contributes to the understanding of the senses: sense, sensation, 
sensism, sensitivity, sensitive, feeling, sensual. These are just the most well known forms; however, their multiple semantic possibilities can be confusing ${ }^{(13)}$. The perceptionist's point of view considers that the sensitive essence exists out of the senses, in the body, or either between the body and the senses, or the organs and the senses. There is a relation between the conscious and belonging to the world, fact and meaning. The language contains the notion of sensation, which is a quality and, therefore, it cannot be a conscious element, but an object characteristic ${ }^{(1)}$.

The sense of smell is the most direct of all senses $^{(5)}$. The "invisibility" of the smells has aroused the interest of philosophic studies. Difficulties in classification, measurement, recreation, manipulation and subjective perception have indicated the sense of smell as a stimulus of difficult empirical handling. Nevertheless, in view of technological progress and multi-professional efforts, the sense of smell has gained new spaces in several knowledge fields, especially in neuroscience laboratories. According to the subjective perception and interpretation of a subject's olfactory memory, the olfactory sensations, due to their emotional and therapeutic reactions (humor, depression, euphoria, irritation, repulse or seduction), may cause the same smell to be either pleasant or unpleasant. Nowadays, smells can be assessed according to parameters like concentration, intensity and characteristics, through complex instruments for analysis and physical-chemical measures of smell emissions, such as olfactometers, nitrogen spectrometers, gas chromatographers, electronic noses and others. However, these instruments cannot define subjective characters, for instance the hedonic tone of a smell or its aesthetic characteristics, according to the olfactory pleasure or displeasure. An attempt for this definition is the "Wheel of Smells", which identified categories by subjective meanings ${ }^{(16)}$. The Nursing Service of the University Hospital/UFSC has, in its health care methodology, a qualifying taxonomy for possible smell phenomena perceived in Nursing activity, which are mostly compatible with the smells in the "offensive" category $^{(16-17)}$.

Bad smells have aroused the greatest scientific interest in the sense of smell ${ }^{(4)}$. Aromatic substances have been scientifically disqualified at the end of the XIX century, because they were a mask for bad smells. After Pasteur's findings, scientists supported that bad smells were sub products of pathologic agents, and medicine turned to the microbes' world and no longer at the smells analysis (miasmas).

Over the last two centuries, smells have gained room in research and the culture of the deodorized body motivates the immensurable production of products that mask the body's smells: deodorants, lotions, soaps, talcum powders and ointments $^{(7)}$. A new appropriation of the sense of smell appears in the market through the commerce of smells, with sanitary/medical products broadly used by nursing professionals. Besides the control of the body's smells, the diagnosis, treatment and inspection of environmental smells are also promoted, in all spaces of human public or private activity.

\section{FINAL CONSIDERATIONS... SOME DEDUCTIONS...}

The aspects presented and those described by Wosny ${ }^{(17)}$ inspire some deductions about the aesthetics of smells and Nursing care.

- Olfactory perceptions and sensations have relevance and meaning, as a phenomenon that is present in Nursing practice in the hospital environment.

- The sense of smell is vital to the human being, essential for life, and provides interaction with nature, confidence, reproduction of the species, and the pleasure of being and living. The human being naturally has the sense of smell, interacts with the environment, perceives and interprets smell sensations according to their aesthetic traits, which can be pleasant, unpleasant, comforting or disturbing. Olfactory sensations, possible through subjective aesthetic interpretations, allow for the expression of feelings and physical or psychological comfort or discomfort.

- The consideration of olfactory sensations and the sense of smell in Nursing care is still limited. Nevertheless, a better aesthetic/philosophical and technical/scientific comprehension of smell emanations will favor Nursing diagnoses and prescription, environmental quality regulation and therapeutics.

- The hospital environment has smell emanations that may designate several meanings, for instance the presence of a biologic agent, risk condition or poor environmental hygiene. Studies about the olfactory perceptions present in the care environment, their origins and causing factors will contribute to the quality of Nursing care and to greater comfort and security for the people in this space or context. 


\section{REFERENCES}

1. Merleau-Ponty M. Fenomenologia da percepção. São Paulo: Martins Fontes; 1996.

2. Ninghtingale F. Notas de enfermagem: o que é e o que não

é. São Paulo: Cortez; 1989.

3. Alcântara LM, Leite JL, Erdmann AL, Trevisan MA, Dantas CC. Enfermería operativa: una nueva perspectiva para el cuidado en situaciones de "crash". Rev Latino-am Enfermagem 2005 maio-junho: 13(3):322-31.

4. Corbin A. Saberes e odores: o olfato e o imaginário social nos séculos XVIII e XIX. São Paulo: Cia. das Letras; 1987. 5. Ackerman D. Uma história natural dos sentidos. São Paulo: Bertrand; 1992.

6. Vigarello G. O limpo e o sujo: uma história da higiene corporal. São Paulo: Martins Fontes; 1996.

7. Classen C, Howes D, Synnott A. Aroma: a história cultural dos odores. Rio de Janeiro: Jorge Zahar; 1996.

8. Kant E. Crítica de la razón práctica: crítica del juicio y fundamentación de la metafísica de las costumbres. Buenos Aires: El Ateneo; 1951.

9. Austin JL. Sentido e Percepção. São Paulo: Martins Fontes; 1993.

10. Cândido M. Uma ontologia do sensível: corporeidade e pensamento de Leonardo Coimbra. Arquipélago Rev Univ Açores 1991; 2(3):163-6.

11. Jovilet R. Tratado de Filosofia II: psicologia. São Paulo: AGIR; 1967.

12. Montaigne ME. Ensaios. 2a ed. São Paulo: Abril Cultural; 1980 .

13. Chaui M. Um convite à filosofia. São Paulo: Editora Ática; 1998.

14. Locke J. Carta acerca da tolerância. 2a ed. São Paulo: Abril Cultural; 1978.

15. Condillac EB. Resumo do tratado das sensações. In: Labrune M, Jaffro L, coordenadores. Gradus Philosophicus: a construção da filosofia ocidental. São Paulo: Mandarim; 1996. 16. McGuinley C, McGuinley M, McGuinley D. Odor Basics, understanding and using odor testing. The 22nd Annual Hawaii Water Environment Association Conference; 2000 june 6-7; Honolulu; Hawaii; 2000

17. Wosny AM. A estética dos odores: o sentido do olfato no cuidado de enfermagem hospitalar. [tese]. Florianópolis (SC): Programa de Pós-Graduação de Enfermagem/UFSC; 2001. 